\title{
Effects of thermal processing on nutritional characteristics and non-volatile flavor components from Tricholoma lobayense
}

\author{
Li-Yuan Zhou, Wan Li, Wen-Juan Pan, Sajid Hussain, Ya Wang, Wen-Qiang Guo, Zheng-Nan Cai, \\ Wei-Wei Yang, Dan-Dan Wang, Yan Chen* \\ Department of Bioengineering, School of life Sciences, Anhui University, Hefei 230601, Anhui, P.R. China
}

\section{A B S T R A C T}

In order to explore a better method to process the fruiting body of Tricholoma lobayense. Through the determination of proximate compositions, total soluble protein, sugar content, amino acids composition and 5 '-nucleotides content, the effects of thermal processing on the nutritional compositions and non-volatile flavor components of the fruiting body of Tricholoma lobayense were evaluated. Our study showed that the level of the proximate compositions, total soluble protein and sugar content in Tricholoma lobayense, reduced except the total phenolics during cooking. Amino acids composition analysis illustrated that the boiling raised total free amino acids content, but microwaving indicated an opposite effect. Boiling and microwaving could considerably raise the total $5^{\prime}$-nucleotides content. Microwaving reduced the EUC (Equivalent umami concentration) while boiling raised EUC. Both boiling and microwaving significantly raised the bio-accessibility of soluble sugar and protein but boiling was almost doubling that of control. All results suggested that boiling method could effectively preserve the nutritional characteristics of Tricholoma lobayense, and make Tricholoma lobayense more delicious and easier to be digested compared with microwaving.

Keywords: Bio-accessibility; Non-volatile flavor components; Nutritional characteristics; Thermal processing; Tricholoma lobayense

\section{INTRODUCTION}

Edible fungus, which have long been cultivated and studied, are widely distributed in Asia and are famous for their abundant nutritive and medicinal value. In general, mushroom contains a lot of carbohydrates and protein, and a little of fat (Kalač, 2009). Proteins from mushroom contain entire essential amino-acids which could only be provided via foods instead of through demic synthesis pathways. Edible fungus contains lower content of total fat and higher content of PUFA ranged from seventytwo to eighty-five percent (Kalač, 2013). Moreover, there is high consumption demand of mushroom, due to the strong flavor and taste. The representative flavor of edible fungus comes from volatile and non-volatile compound (Phat et al., 2016). Non-volatile ingredients include polyols, soluble saccharides, 5'-nucleotides as well as free aminoacids which are pivotal to the taste of mushrooms (Tian et al., 2016). 5'-nucleotides and monosodium glutamate
(MSG) commonly induce or enhance umami, which acts as the No.5 gustation in addition to 4 fundamental gustation including saline taste, bitterness taste, sweet taste as well as sour taste. Equivalent umami concentrations (EUC) of mushrooms, which are the MSG concentration amounting to the intensity of umami originated from mixed 5'-nucleotides and MSG, were calculated by Mau (2005), according to non-volatile ingredient levels.

Edible fungus is commonly dried for preservation or applied in the production of pickles, condiments, puree or canned food. The nutritional properties of mushrooms can be altered by the processing, which influences mushrooms' chemical composition. Consumers consider that process with high temperature could have deleterious effects on food's chemical composition. Manzi et al. (2004) have examined proximate composition and some nutritional components, such as chitin, $\beta$-glucan, dietary fiber and total phenols in untreated and cooked products.

\footnotetext{
*Corresponding author:

Yan Chen, School of Life Sciences, Anhui University, Hefei 230601, Anhui, P.R. China. Tel/Fax: +86 55163861751.

E-mail: chenyan91030@yahoo.com
}

Received: 08 December 2016;

Revised: 08 February 2017;

Accepted: 14 February 2017;

Published Online: 24 February 2017 
Meanwhile, the flavor compounds of mushrooms changed due to various chemical reactions during processes. The changes in taste components have been examined by many studies. It was revealed by $\mathrm{Li}$ et al. (2011) that non-volatile compositions in mushroom soup could be influenced by different cooking methods due to many reactions (the Maillard reaction). Chiang et al. (2006) revealed that non-volatile component content had been markedly decreased in canned mushroom. Previous results suggested that some thermal processing could affect nutritional characteristics and the taste of mushrooms. However, no reports have illustrated the change of EUC during cooking.

The bio-accessibility of nutrients has a very important position in researches on bromatology and nutriology. The ingredient of a nutriment after digestion, which could be utilized by organisms, is significant. The bio-accessibility of nutrients is influenced by many factors: The chemical state of the nutrient, potential interactions with other food components, the releasing condition, co-existing suppressive factors or co-factors as well as generated substances with slow metabolizing velocity. Nevertheless, the bio-accessibility may be improved by food processing, for example, polishing, fermenting as well as heating which is probably due to disrupted cellular wall, dissociation of matrix and nutrient complex, or higher reactivity resulted from structural change (Parada and Aguilera, 2007). Carbohydrates and proteins are the main macromolecular nutrients of mushrooms. Therefore it is necessary to study the effect of cooking methods on the bio-accessibility of carbohydrates and proteins.

Tricholoma lobayense Heim, a kind of valuable precious edible fungus, is commercially cultivated for the health food market. It is not only abundant in nutrients but also palatable. Many important bioactive compounds in Tricholoma lobayense Heim exhibited immunomodulation and antitumor activity (Liu et al., 1996). Our previous study of in vitro antioxidant activities revealed that TLH-3 among the T.lobayense polysaccharides had the strongest antioxidant activity (Wang et al., 2012). Related experts pointed out that $T$. lobayense Heim could become a popular commodity domestically in annuals to come. Until now, it is ascertained by our document research that systematic studies on nutritional characteristics and taste components of T.lobayenseare extremely limited.

It was aimed to compare and examine the variety of nutritional characteristics and non-volatile taste ingredients from Tricholoma lobayense Heim in different cooking methods. The study focused on total phenols, total soluble sugars, total soluble proteins, 5'-nucleotides as well as free amino-acids, even change of bio-accessibility of total soluble sugars and total soluble proteins in vitro gastrointestinal digestion.

\section{MATERIALS AND METHODS}

\section{Sampling}

Fresh fruiting bodies of Tricholoma lobayense (FBTL) were purchased from Hainan Qingqing Agriculture Co., Ltd. in Hainan province, P.R. China; they were cut into small pieces before cooking procedure. The FBTL were divided into three portions, processed with different cooking treatments.

\section{Cooking}

Boiling: Mushroom samples (100 g) were soaked in $1000 \mathrm{~mL}$ distilled water. The soaked mixture was cooked to tender for 15 min using induction cooker (DL-D100, Donlim, China) at 400W (Thermal efficiency: $86 \%$ ). Then the surface water was removed.

Microwaving: Mushroom samples $(100 \mathrm{~g})$ were placed in a glass beaker containing $1000 \mathrm{~mL}$ distilled water, and cooked to tender for $10 \mathrm{~min}$ in a microwave oven (P70D20AP-TD(w0), Galanze, China) at 900 Watts (Thermal efficiency:58\%). Then the surface water was removed.

FBTL treated with different ways were freeze-dried. Three dried samples were randomly grinded to obtain coarse powder (8 openings/ $\mathrm{cm})$.

\section{Proximate composition determination}

The proximate compositions of the three different samples, including crude ash, crude fat, crude protein, were determined using the AOAC (2012). The nitrogen factor used for crude protein calculation was 4.38 (Liu et al., 2014). All results were showed as g $100 \mathrm{~g}^{-1}$ dry weight (DW).

\section{Total soluble protein and sugar determination}

Total soluble protein and sugar were extracted and analyzed as Sun et al. with some modifications (Sun et al., 2011). Samples $(100 \mathrm{mg})$ were polished, homogenized after adding $5 \mathrm{~mL}$ PBS $(50 \mathrm{mM}, \mathrm{pH} 7.8)$, then were centrifuged at $10,000 \mathrm{rpm}$ at $4^{\circ} \mathrm{C}$ for $15 \mathrm{~min}$. Total soluble protein content in the supernatant was analyzed based on a calibration curve of bovine serum albumin. Results were showed as $\mathrm{g} / 100 \mathrm{gDW}$.

Samples $(100 \mathrm{mg})$ were polished and added with $5 \mathrm{~mL}$ distilled water in $80^{\circ} \mathrm{C}$ for $2.5 \mathrm{~h}$, then centrifuged at $10,000 \mathrm{rpm}$ at $4^{\circ} \mathrm{C}$ for $20 \mathrm{~min}$. Total soluble sugar content in the supernatant was analyzed based on a calibration curve of glucose. Results were showed as g $100 \mathrm{~g}^{-1} \mathrm{DW}$. 


\section{Total phenolic content determination}

For total phenolic extraction according to Jiang et al. with some modifications (Jiang et al., 2015), dried samples (0.5 g) was homogenised with $5 \mathrm{~mL} 80 \%$ ethanol solution for $5 \mathrm{~min}$. After $2 \mathrm{~h}$ in the dark, the slurry was centrifuged at $10,000 \mathrm{rpm}$ at $4^{\circ} \mathrm{C}$ for $15 \mathrm{~min}$. Afterwards, total phenolic in the supernatant was determined according to the method of Li et al. with some modifications (Li et al., 2014). In brief, total phenolic content was assessed by blending $200 \mu \mathrm{L}$ of deionised water, $50 \mu \mathrm{L}$ of the diluted extracts, and $50 \mu \mathrm{L}$ of Folin-Ciocalteu reagent. Six minutes later, $500 \mu \mathrm{L}$ of $7.5 \%$ $\mathrm{Na}_{2} \mathrm{CO}_{3}$ was added, then the distilled water was added to make the mixture volume to $1.3 \mathrm{~mL}$ and allowed to stand at room temperature for $60 \mathrm{~min}$. At $765 \mathrm{~nm}$ the mixture absorbance was read using a Microplate reader (Spectra MAX-M2e, Molecular Devices, USA). The calibration curve was constructed using gallic acid (ranging from 0 to $\left.100 \mu \mathrm{g} \mathrm{mL}^{-1}, \mathrm{R}^{2}=0.9968\right)$. The results were showed as $\mathrm{mg}$ of gallic acid equivalents (GAE) $100 \mathrm{~g}^{-1} \mathrm{DW}$.

\section{Analysis for free amino acids}

The free amino acid contents of the samples were determined using the methods of Melo-Ruiz et al. (2015). Dried samples $(0.5 \mathrm{~g})$ were extracted with $50 \mathrm{~mL}$ of 0.1 $\mathrm{M} \mathrm{HCl}$. The sample was stood at room temperature for $45 \mathrm{~min}$ and then centrifuged at 10,000 rpm for $15 \mathrm{~min}$. The collected supernatant liquid was filtered with a MCE syringe filter and the resulting liquid was determined by an amino acids analyzer (S-433D, SYKAM, Germany).

\section{Analysis for $\mathbf{5}^{\prime}$-nucleotide}

The nucleotides were extracted using a modified method of Wang et al. (2016). Dried samples $(500 \mathrm{mg})$ were grinded fully, and extracted with $10 \mathrm{~mL}$ of distilled water. The suspension was placed in a water bath $\left(100^{\circ} \mathrm{C}\right)$ for $1 \mathrm{~min}$, stirred for 15 min until cooling to room temperature and then centrifuged at $10,000 \mathrm{rpm}$ for $20 \mathrm{~min}$. The precipitation was extracted for two times with $10 \mathrm{~mL}$ of distilled water. All supernatant was evaporated and re-dissolved in a final volume of $10 \mathrm{~mL}$ with distilled water, then filtrated with a $0.22-\mu \mathrm{m}$ MCE syringe filter before HPLC.

5'-Nucleotides were analyzed as described by Tsai et al. (2009). The assay was performed on a Zorbax Eclipse XDB C18 column $\left(4.6 \times 150,5 \mu \mathrm{m}\right.$, Agilent), controlled at $30^{\circ} \mathrm{C}$ temperature. The $\mathrm{H}_{2} \mathrm{O} / \mathrm{CH}_{3} \mathrm{OH} / \mathrm{CH}_{3} \mathrm{COOH} / \mathrm{C}_{16} \mathrm{H}_{37} \mathrm{NO}$ (tetrabutylammonium hydroxide) $(894.5 / 100 / 5 / 0.5, \mathrm{v} / \mathrm{v} /$ $\mathrm{v} / \mathrm{v}$ ) was used as the mobile phase, and the flow rate was $0.7 \mathrm{~mL} / \mathrm{min}$. All samples were detected by UV at $254 \mathrm{~nm}$ with $10 \mu \mathrm{L}$ injection volume. All 5'-nucleotides were identified and quantified by constructing the calibration curve, using the authentic 5'-nucleotide (Aladdin Reagent (Shanghai) Co., Ltd, Shanghai, China).

\section{Equivalent umami concentration (EUC)}

The EUC value (mg MSG/g) reflects the concentration of MSG, which is equivalent to the umami intensity given by a mixture of MSG and 5'-nucleotides. The EUC value is calculated by the following equation (Yamaguchi et al., 1971):

$$
Y=\sum a_{i} b_{i}+1.218\left(\sum a_{i} b_{i}\right)\left(\sum a_{j} b_{j}\right)
$$

Y: The EUC of the mixture (mg MSG/100 g);

$a_{i}$ : The concentration $(\mathrm{mg} / 100 \mathrm{~g})$ of each umami amino acid [aspartic acid (Asp) or glutamic acid (Glu)];

$\mathrm{a}_{\mathrm{i}}$ : The concentration $(\mathrm{mg} / 100 \mathrm{~g})$ of each umami 5'-nucleotide [5'-inosine monophosphate (5'-IMP), 5'-guanosine monophosphate (5'-GMP), 5'-xanthosine monophosphate(5'-XMP) or 5'-adenosine monophosphate (5'-AMP)];

$b_{i}$ : The relative umami concentration (RUC) for each umami amino acid to MSG (Glu, 1 and Asp, 0.077);

$b_{:}$: The RUC for each umami 5'-nucleotide to 5'-IMP (5'-IMP, 1; 5'-GMP, 2.3; 5'-XMP, 0.61 and 5'-AMP, 0.18 ); and 1.218 is a synergistic constant based on the concentration (mg/100 g) used.

\section{In vitro gastrointestinal digestion}

The in vitro gastrointestinal digestion could be divided into two successive phases: Gastric and intestinal digestion, as previously reported by Rodríguez-Roque et al. with some modifications (Rodríguez-Roque et al., 2013).

Gastric digestion: Dried samples (1.00 g) were ground with $100 \mathrm{~mL}$ of distilled water. Then the $\mathrm{pH}$ was adjusted immediately to 2.00 by addition of $\mathrm{HCl}(12 \mathrm{M}) .15,720$ Units of pepsin were added and the mixture was incubated at $37^{\circ} \mathrm{C}$ and $90 \mathrm{rpm}$ for 2 hours in an air bath shaker (HQ45, China). After the 2-hour incubation, aliquots of $30 \mathrm{~mL}$ were collected from each vessel and centrifuged using a SIGMA 3K15 centrifuge at $10,000 \mathrm{rpm}$ at $4^{\circ} \mathrm{C}$ for $15 \mathrm{~min}$. The supernatant was stored at $-20^{\circ} \mathrm{C}$ for further analysis.

Intestinal digestion: Dialysis bag was held with $25 \mathrm{~mL}$ water- $\mathrm{NaHCO}_{3}(0.5 \mathrm{~N})$ mixture to make the gastric digest $\mathrm{pH}$ 7.5. To simulate intestinal digestion, the dialysis bag (containing the water- $\mathrm{NaHCO}_{3}$ mixture) was completely immersed in that digest until reaching $\mathrm{pH}$ 5.0. Later, $5 \mathrm{~mL}$ of pancreatin $(4 \mathrm{~g} / \mathrm{L})$ - bile $(25 \mathrm{~g} / \mathrm{L})$ mixture was added, and the incubation lasted for $2 \mathrm{~h}$ at $37^{\circ} \mathrm{C}$ and $90 \mathrm{rpm}$. The dialysis bag was removed and washed with distilled water, then the dialysate was studied. Therefore, two fractions were got after intestinal digestion: Duodenal and dialysed fractions. Aliquots were collected after each digestive phase and immediately cooled to room temperature. Afterwards, aliquots were frozen $\left(-20^{\circ} \mathrm{C}\right)$ until the analyses of total soluble protein and total soluble sugar. 
Bio-accessibility was considered as the concentration of bioactive compounds released from the food matrix by in vitro gastrointestinal digestion. Bio-accessibility was calculated using the following formula (Rodríguez-Roque et al., 2013):

Bio $-\operatorname{accessibility}(\%)=\left(\frac{C \text { dialysed }}{C \text { non }- \text { digested }}\right) * 100$

where $\mathrm{C}_{\text {dialysed }}$ and $\mathrm{C}_{\text {non-digested }}$ referred to the nutrient content concentration $(\mathrm{mg} / 100 \mathrm{~mL})$ in dialysed fraction and nondigested samples (as initially determined from samples), respectively.

\section{Statistical analysis}

All experiments were performed three times. The results were expressed as mean \pm standard deviation (SD). The analysis of variance was executed using one-way analysis of variance (ANOVA). The differences between the means of samples were analyzed by Duncan's test at a significance level of 0.05 .

\section{RESULTS AND DISCUSSION}

\section{Effects of thermal processing on chemical components} The proximate compositions of the samples are listed in Fig. 1A. Crude protein content of untreated samples

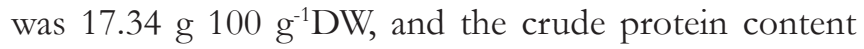

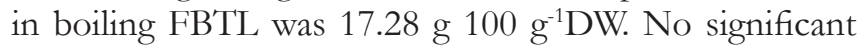
differences were observed between control and boiling treatment. However, microwaving treatment caused a reduction in crude protein to $90.25 \%$ and its effect was significantly higher than that of boiling. Previous studies revealed that these reductions might be related to the protein denaturation at high temperature (Ahmed and Ali, 2013). It has been reported that there is much protein and a little lipid in the mushrooms. In our results, lipid content

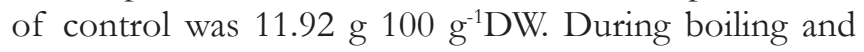
microwaving processes, the total lipid content decreased by $20.22 \%$ and $54.36 \%$, respectively. Both processes showed a decrease in ash contents of FBTL, whereas microwaving displayed higher effect.

The total soluble sugar and protein contents of untreated and processed FBTL were listed in Fig. 1B. In untreated samples, the total sugar and protein were 30.32 and $2.84 \mathrm{~g}$ $100 \mathrm{~g}^{-1} \mathrm{DW}$, respectively. Their contents could be reduced by the methods of boiling and microwaving. The lowest contents of total soluble sugar and protein were displayed in microwaving treatment group, which are 25.41 and $0.95 \mathrm{~g} 100 \mathrm{~g}^{-1} \mathrm{DW}$, respectively. The effects of both heat treatments on total soluble sugar and protein had obviously differences. The two heat treatment methods have little

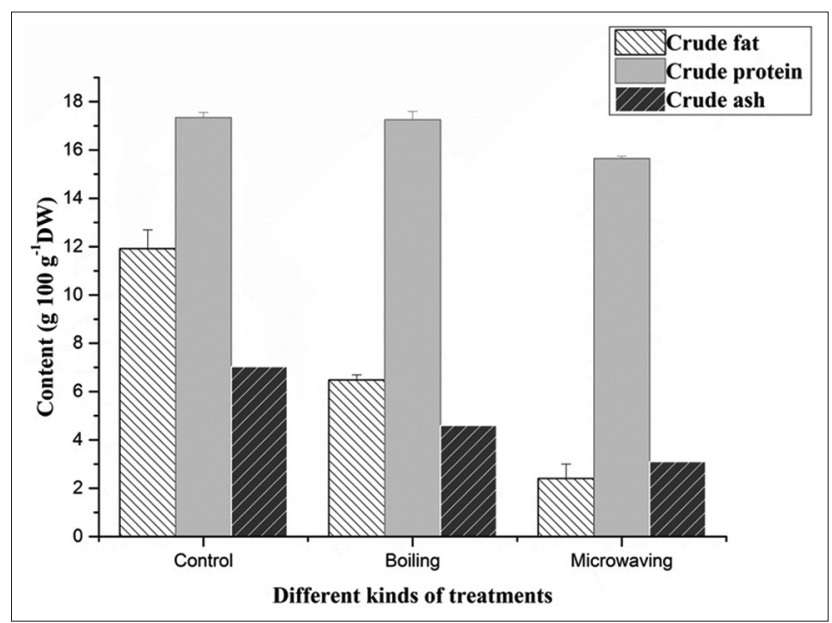

Fig 1A. The proximate composition of untreated and processed FBTL on dry weight basis. Results represent the means of three experiments $(p<0.05)$.

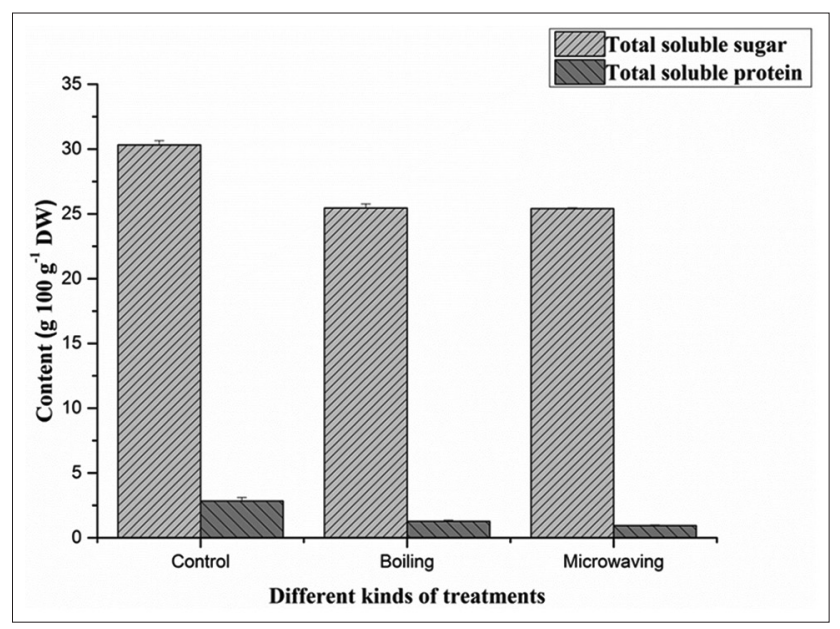

Fig 1B. Total soluble sugar and protein contents of untreated and processed FBTL on dry weight basis. Results represent the means of three experiments $(p<0.05)$.

impact on the total soluble sugar content. However, the effect of microwaving on total soluble protein was significantly higher than that of boiling. Our study were in good agreement with the results Sun et al. (2011), which suggested that heat treatment could significantly reduced the total sugars and proteins contents in Agaricus blazei Murril. It could be explained that some soluble sugars and proteins in FBTL were diffused from tissue to peripheral water.

Phenolic content contributes to the antioxidant activity in Tricholoma lobayense. Therefore, it is necessary to investigate the change in total phenolic content. Fig. 2 showed the effect of different cooking methods on the total phenolic content of FBTL. In our work, the initial level of the total phenolic in dried FBTL was 98.79 mg GAE $100 \mathrm{~g}^{-1}$ DW. After cooking procedures, the total phenolic content 


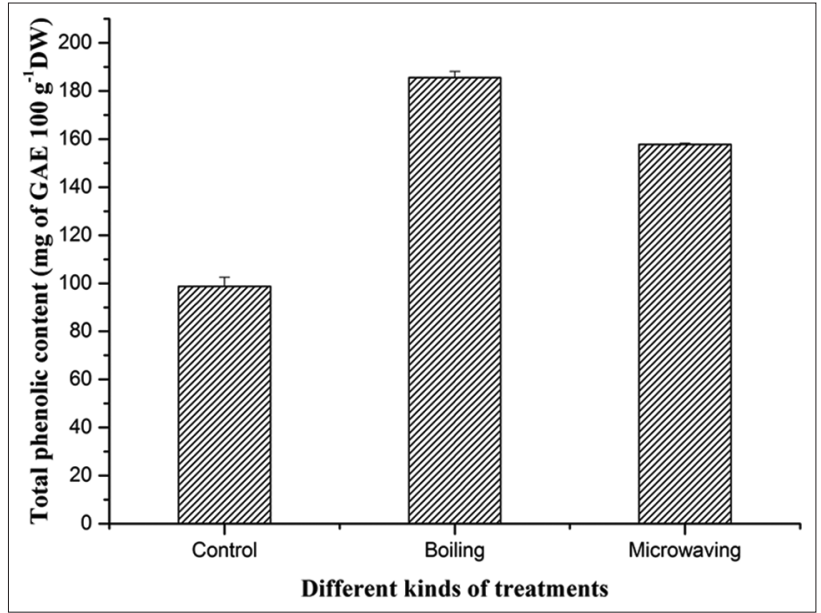

Fig 2. Total phenolic content of untreated and processed FBTL on dry weight basis. Results represent the means of three experiments $(p<0.05)$.

was significantly $(p<0.05)$ raised to $185.61 \mathrm{mg}$ GAE $100 \mathrm{~g}^{-1}$ DW for boiling and $157.84 \mathrm{mg}^{\mathrm{GAE}} 100 \mathrm{~g}^{-1} \mathrm{DW}$ for microwaving compared with control. Boiling resulted in higher total phenolic content than microwaving. The result was consistent with Choi et al. (2006), who reported that heat treatment of Shiitake sample raised the total phenolic content. It was presumed that heat treatment might produce changes due to the destruction of the cell wall, thus bound polyphenolic could be released more easily (Peleg et al., 1991).

\section{Effect of thermal processing on free amino acids}

Several studies referred that mushrooms contain essential amino acids such as leucine, valine, threonine, lysine, methionine, and tryptophan. It was found that threonine and lysine were the major essential free amino acids in all edible fungus (Beluhan and Ranogajec, 2011). The content of free amino acids in samples was shown in Table 1. Thirteen free amino acids were detected in our untreated and processed FBTL. The total amount of 13 free amino acids in FBTL was $17.07 \mathrm{mg} / \mathrm{g}$ DW. In general, due to the mechanism of heat transfer and the particular tissue under treatment, the composition in nitrogenous compounds may change with heat treatment. Based on the results, the content of total free amino acids in boiling and microwaving FBTL should reduce, as a result of condensation between amino groups of amino acids with sugar in mushroom tissue, called maillard reaction (Candela et al., 1997). Table 1 shows that microwaving brought about a reduction of $25.01 \%$ in total free amino acids content, which is same as expected. But the total free amino acids content from boiling was raised to $18.68 \mathrm{mg} / \mathrm{g}$ DW. This result might be due to some free amino acids. These free amino acids includes $_{\mathrm{L}}$-glutamine (from 0.21 to $0.27 \mathrm{mg} / \mathrm{g} \mathrm{DW}$ ), ${ }_{\mathrm{L}}$-valine (from 0.74 to $0.91 \mathrm{mg} / \mathrm{g} \mathrm{DW}$ ), ${ }_{\mathrm{L}}$-isoleucine (from 0.44 to $0.66 \mathrm{mg} / \mathrm{g} \mathrm{DW}$ ), ${ }_{\mathrm{L}}$-Leucine (from 0.88 to $1.62 \mathrm{mg} / \mathrm{g} \mathrm{DW}$ ),
Table 1: Free amino acids contents of untreated and processed FBTL on dry weight basis, each value is expressed as mean $\pm S D(n=3)$

\begin{tabular}{lccc}
\hline Free amino acids & \multicolumn{3}{c}{ Content (mg/g dry weight) } \\
\cline { 2 - 4 } & Control & Boiling & Microwaving \\
\hline Asp & $0.21 \pm 0.02 \mathrm{~b}$ & $0.27 \pm 0.03 \mathrm{a}$ & $0.17 \pm 0.01 \mathrm{~b}$ \\
Ser & $3.62 \pm 0.03 \mathrm{a}$ & $3.34 \pm 0.06 \mathrm{a}$ & $2.35 \pm 0.06 \mathrm{~b}$ \\
Glu & $1.78 \pm 0.01 \mathrm{a}$ & $1.73 \pm 0.09 \mathrm{a}$ & $1.24 \pm 0.11 \mathrm{~b}$ \\
Gly & $1.14 \pm 0.07 \mathrm{a}$ & $1.03 \pm 0.05 \mathrm{a}$ & $0.67 \pm 0.13 \mathrm{~b}$ \\
Ala & $4.23 \pm 0.06 \mathrm{a}$ & $3.99 \pm 0.08 \mathrm{a}$ & $2.98 \pm 0.14 \mathrm{~b}$ \\
Val & $0.74 \pm 0.09 \mathrm{~b}$ & $0.91 \pm 0.08 \mathrm{a}$ & $0.68 \pm 0.01 \mathrm{c}$ \\
Ile & $0.44 \pm 0.10 \mathrm{~b}$ & $0.66 \pm 0.01 \mathrm{a}$ & $0.40 \pm 0.06 \mathrm{~b}$ \\
Leu & $0.88 \pm 0.11 \mathrm{~b}$ & $1.62 \pm 0.09 \mathrm{a}$ & $0.70 \pm 0.08 \mathrm{~b}$ \\
Tyr & $0.62 \pm 0.06 \mathrm{a}$ & $0.68 \pm 0.11 \mathrm{a}$ & $0.37 \pm 0.03 \mathrm{~b}$ \\
Phe & $1.00 \pm 0.05 \mathrm{~b}$ & $1.25 \pm 0.12 \mathrm{a}$ & $0.78 \pm 0.07 \mathrm{c}$ \\
His & $1.26 \pm 0.04 \mathrm{~b}$ & $1.55 \pm 0.10 \mathrm{a}$ & $1.28 \pm 0.04 \mathrm{~b}$ \\
Lys & $0.72 \pm 0.06 \mathrm{c}$ & $1.40 \pm 0.07 \mathrm{a}$ & $1.01 \pm 0.10 \mathrm{~b}$ \\
Arg & $0.43 \pm 0.13 \mathrm{a}$ & $0.25 \pm 0.14 \mathrm{~b}$ & $0.17 \pm 0.06 \mathrm{c}$ \\
Bitter & $4.75 \pm 0.0 .52 \mathrm{~b}$ & $6.24 \pm 0.54 \mathrm{a}$ & $4.01 \pm 0.32 \mathrm{c}$ \\
MSG-like & $1.99 \pm 0.03 \mathrm{a}$ & $2.00 \pm 0.12 \mathrm{a}$ & $1.41 \pm 0.12 \mathrm{~b}$ \\
Sweet & $4.76 \pm 0.16 \mathrm{a}$ & $4.37 \pm 0.19 \mathrm{a}$ & $3.02 \pm 0.33 \mathrm{~b}$ \\
Tasteless & $1.34 \pm 0.12 \mathrm{~b}$ & $2.08 \pm 0.18 \mathrm{a}$ & $1.38 \pm 0.13 \mathrm{~b}$ \\
Total & $17.07 \pm 0.83 \mathrm{a}$ & $18.68 \pm 1.03 \mathrm{a}$ & $12.80 \pm 0.90 \mathrm{~b}$ \\
\hline
\end{tabular}

Means with different letters within a row are significantly different $(p<0.05)$ aAla, L-Alanine; Arg, L-Arginine; Asp, L-Aspartic acid; Glu,

L-Glutamic acid; Gly, Glycine; His, L-Histidine; lle, L-Isoleucine; Leu, L-Leucine; Lys, L-Lysine; Phe, L-Phenylalanine; Ser, L-Serine; Tyr, L-Tyrosine; Val, L-Valine; bMSG-like: Asp+Glu; Sweet: Ala+Gly+Ser+Thr; Bitter: Arg+His+lle+Leu+Met+Phe+Val; Tasteless: Lys+Tyr;

L-tyrosine (from 0.62 to $0.68 \mathrm{mg} / \mathrm{g} \mathrm{DW}$ ), ${ }_{\mathrm{L}}$-phenylalanine (from 1.00 to $1.25 \mathrm{mg} / \mathrm{g} \mathrm{DW}$ ), L-histidine (from 1.26 to $1.55 \mathrm{mg} / \mathrm{g} \mathrm{DW}$ ) and L-lysine (from 0.72 to $1.40 \mathrm{mg} / \mathrm{gDW}$ ), which were released from the proteolysis during heating (Pei et al., 2014).

According to the classification described by Mau et al. (2001), free amino acids in edible mushrooms were divided into four groups in accordance with their taste characteristics. They were monosodium glutamate-like (MSG-like) acids (aspartic and glutamic), sweet taste amino acids (alanine, glycine, serine and threonine), bitter amino acids (arginine, histidine, isoleucine, leucine, methionine, phenylalanine, and valine), and tasteless amino acids (lysine and tyrosine). It has been reported that the MSG-like and sweet components may be responsible for the natural taste of mushrooms (Beluhan et al., 2011). The sweetness from sweet components comprised mainly of high amounts of soluble sugars and polyols could probably mask the bitter taste produced by the bitter components in mushrooms. Liu et al. (2014) suggested that the taste-active MSG-like and sweet acids in common mushrooms would be the main reason of the delightful taste of mushrooms. After processing, the amount of MSG-like in microwaving FBTL $(1.41 \mathrm{mg} / \mathrm{g} \mathrm{DW})$ was lower than that in untreated FBTL $(1.99 \mathrm{mg} / \mathrm{g}$ DW), but the amount of MSG-like in boiling $(2.00 \mathrm{mg} / \mathrm{g} \mathrm{DW})$ was almost the same with the un-processed as shown in Table 1. The results also 
showed that the amount of sweet amino acids in boiling $(4.37 \mathrm{mg} / \mathrm{g} \mathrm{DW})$ and microwaving $(3.02 \mathrm{mg} / \mathrm{g} \mathrm{DW})$ treatment group were also lower than the control group $(4.76 \mathrm{mg} / \mathrm{g} \mathrm{DW})$. Our results suggested that the taste of boiling FBTL was better than that of microwaving.

\section{Effect of thermal processing on $\mathbf{5}^{\prime}$-nucleotides}

The amount of 5'-nucleotides in untreated and processed FBTL was shown in Table 2. The content of total 5'-nucleotides in untreated FBTL was $2.22 \mathrm{mg} / \mathrm{g} \mathrm{DW}$. After cooking, the total 5'-nucleotides content was raised to 3.33 and $3.19 \mathrm{mg} / \mathrm{g}$ DW by boiling and microwaving respectively. Table 2 showed that 5'-CMP $(1.39 \mathrm{mg} / \mathrm{g} \mathrm{DW})$ occupied the high content of 5'-nucleotides, which was consistent with Tsai et al. (2009). 5'-GMP was a flavor enhancer much stronger than MSG with a meaty flavor, while the flavor could be enhanced by 5'-IMP with other 5'-nucleotides (Pei et al., 2014). Furthermore, the sweet taste could be provided by 5'-AMP for mushroom, and 5'-AMP also has the effective inhibition on bitter taste (Leksrisompong et al., 2012). Our results showed that the 5'-GMP and 5'-AMP content, consistent with the variety of total 5'-nucleotides content, raised during different cooking methods, which could assign to the degradation of deoxyribonucleic acid or ribonucleic acid in FBTL when cooking (Claudine et al., 2005). However, 5'-IMP content reduced during boiling (from 0.15 to $0.11 \mathrm{mg} / \mathrm{g} \mathrm{DW}$ ) and microwaving (from 0.15 to $0.10 \mathrm{mg} / \mathrm{g} \mathrm{DW})$. It may be explained that 5'-IMP was susceptible of thermal sensitivity, which make 5'-IMP become ribose (Van Boekel, 2006).

Both flavors of MSG-like components and 5'-nucleotides played an important role in enhancing the umami taste of mushrooms (Yamaguchi et al.,1971). Mau (2005) reported that the mushrooms were classified into four levels according to the calculated EUC values of flavor components:>1000\% (>1000 g MSG/100 g DW), 100-1000\% (100-1000 g MSG/100 g DW), 10-100\% (10-100 g MSG/100 g DW), $<10 \%$ (<10 g MSG/100 gDW). Table 3 shows that EUC value of the FBTL $(31.65 \mathrm{~g}$ MSG/100 g DW) was at the third level. After cooking, the EUC value of microwaving FBTL significantly $(p<0.05)$ decreased to $24.85 \mathrm{~g}$ MSG $/ 100 \mathrm{~g}$ DW. But the EUC value of boiling FBTL was raised to $39.92 \mathrm{~g}$ MSG/100 $\mathrm{g}$ DW. The results indicated that boiling could enhance the umami taste of FBTL.

\section{Effect of thermal processing on the bio-accessibility of soluble sugar and protein by in vitro gastrointestinal digestion}

Effect of cooking on the bio-accessibility of soluble sugar and protein by in vitro gastrointestinal digestion is presented in Table 4. The results showed that cooking
Table 2: Content of free 5'-nucleotides in untreated and processed FBTL on dry weight basis

\begin{tabular}{lccc}
\hline 5'-Nucleotide & \multicolumn{3}{c}{ Content (mg/g dry weight) } \\
\cline { 2 - 4 } & Control & Boiling & Microwaving \\
\hline 5'-AMP & $0.13 \pm 0.01 \mathrm{~b}$ & $0.16 \pm 0.02 \mathrm{a}$ & $0.14 \pm 0.01 \mathrm{~b}$ \\
5'-CMP & $1.39 \pm 0.01 \mathrm{~b}$ & $2.31 \pm 0.05 \mathrm{a}$ & $2.30 \pm 0.20 \mathrm{a}$ \\
5'-GMP & $0.55 \pm 0.03 \mathrm{~b}$ & $0.75 \pm 0.06 \mathrm{a}$ & $0.65 \pm 0.05 \mathrm{~b}$ \\
5'-IMP & $0.15 \pm 0.01 \mathrm{a}$ & $0.11 \pm 0.01 \mathrm{a}$ & $0.10 \pm 0.01 \mathrm{a}$ \\
Total & $2.22 \pm 0.06 \mathrm{~b}$ & $3.33 \pm 0.14 \mathrm{a}$ & $3.19 \pm 0.27 \mathrm{a}$
\end{tabular}

Means with different letters within a row are significantly different $(p<0.05)$, 5'-AMP, 5'-adenosine monophosphate; 5'-CMP, 5'-cytosine

monophosphate; 5'-GMP, 5'-guano-sine monophosphate; 5'-IMP, 5'-inosine monophosphate;

Table 3: The EUC of untreated and processed FBTL on dry weight basis

\begin{tabular}{lc}
\hline Samples & EUC (g MSG/100 g dry weight) \\
\hline Control & $31.65 \pm 1.56 \mathrm{a}$ \\
Boiling & $39.92 \pm 2.25 \mathrm{~b}$ \\
Microwaving & $24.85 \pm 0.96 \mathrm{c}$ \\
\hline
\end{tabular}

Each value is expressed as mean $\pm S D(n=3)$, means with different letters within a row are significantly different $(p<0.05)$

could significantly raise the bio-accessibility of soluble sugar and protein.

For the total soluble protein, after gastric digestion, small amounts of soluble protein were detected in stomach from three different samples. It was found that after intestinal digestion, the soluble protein was raised. The increase in water-soluble low molecular components level might result in the change, because of the activity of fungal proteolytic enzymes (Agosin et al., 1989). But the bio-accessibility of the soluble protein with different cooking methods (boiling and microwaving, being $21.38 \%$ and $19.74 \%$, respectively) raised about 1 -fold than the untreated samples. The increase of soluble protein bio-accessibility after cooking can be explained by heat-degradation of proteins which occurred during cooking and the removal of anti-nutrients that inhibit protein digestion, such as trypsin inhibitors and inositol phosphates (Stodolak and Anna, 2008).

Table 4 revealed that two different cooking methods could also raise the bio-accessibility of total soluble sugar, compared with untreated FBTL $(33.25 \%)$. The affection of boiling on bio-accessibility of total soluble sugar $(71.25 \%)$ was stronger than that of microwaving (62.17\%). Englyst and Englyst (2005) reported that there was a central position in the food matrix in the concept of carbohydrate bioaccessibility. In crude plant foods, the cell wall NSP played a structural role in maintaining the integrity of the cells. NSP produced an encapsulation effect, which limited the sugars digested and absorbed in the small intestine. Since excessive food processing destroyed the encapsulation effect, our results were consistent with Englyst and Englyst. The reason of consistency might be that the encapsulation was 
Zhou, et al.: The effect of thermal processing on T. lobayense

Table 4: Concentration of total soluble protein and total soluble sugar by in vitro digestion of untreated and processed FBLT

\begin{tabular}{|c|c|c|c|c|c|}
\hline \multirow[t]{3}{*}{ Sample } & \multicolumn{4}{|c|}{ Concentration $(\mathrm{mg} / 100 \mathrm{ml})$} & \multirow[t]{3}{*}{ Bio-accessibility (\%) } \\
\hline & \multirow[t]{2}{*}{ Non-digested } & \multirow[t]{2}{*}{ Gastric digestion } & \multicolumn{2}{|c|}{ Intestinal digestion } & \\
\hline & & & Duodenal fraction & Dialysed fraction & \\
\hline \multicolumn{6}{|c|}{ Total soluble protein } \\
\hline Control & $28.09 \pm 0.42 a$ & $2.70 \pm 0.04 d$ & $26.55 \pm 0.64 b$ & $3.04 \pm 0.01 \mathrm{c}$ & 10.81 \\
\hline Boiling & $12.50 \pm 0.24 b$ & $2.58 \pm 0.03 \mathrm{c}$ & $30.88 \pm 1.00 a$ & $2.67 \pm 0.04 \mathrm{c}$ & 21.38 \\
\hline Microwaving & $8.90 \pm 0.63 b$ & $9.16 \pm 0.07 b$ & $31.53 \pm 0.69 a$ & $1.81 \pm 0.32 \mathrm{c}$ & 19.74 \\
\hline \multicolumn{6}{|c|}{ Total soluble sugar } \\
\hline Control & $303.14 \pm 5.32 a$ & $18.08 \pm 1.17 \mathrm{c}$ & $101.66 \pm 1.71 b$ & $100.82 \pm 7.36 b$ & 33.25 \\
\hline Boiling & $254.55 \pm 4.33 a$ & $246.82 \pm 5.53 a$ & $221.90 \pm 7.82 b$ & $181.32 \pm 7.43 c$ & 71.25 \\
\hline Microwaving & $252.00 \pm 2.60 a$ & $266.63 \pm 8.06 a$ & $168.76 \pm 8.08 b$ & $158.0 \pm 3.75 b$ & 62.17 \\
\hline
\end{tabular}

Results are given as the average values \pm standard deviation of three independent samples, different letters in the columns represent statistically significant differences $(p<0.05)$, the terms represent: Non-digested, as initially determined from sample matrix using $80 \%$ aqueous ethanol

disrupted when heated in the presence of water, so the sugar was freed from the cell and easily susceptible to digestion.

\section{CONCLUSIONS}

The present study indicated that the nutritional components including crude protein, crude fat, ash, total soluble protein and total soluble sugar reduced by the boiling and microwaving treatments, while the total phenolic was raised. Furthermore, our results showed an obvious effect of boiling and microwaving on free amino acids and 5'-nucleotides. Boiling raised the total free amino acids while microwaving reduced the total free amino acids content. Both treatments raised the 5'-nucleotides content. The EUC, which was affected by free amino acids and 5'-nucleotides, changed with different treatments. Our results suggested that boiling could raise the EUC but microwaving reduced the EUC. In addition, we have studied the effects of cooking on the bio-accessibility of soluble sugar and protein by in vitro gastrointestinal digestion. The bio-accessibility with different cooking methods was significantly higher than that in untreated FBTL measured by the total soluble protein or total soluble sugar. But the bio-accessibility of boiling was higher than that of microwaving. Our study recommends that the quality of boiling FBTL is better than the quality of microwaving FBTL in nutrition, taste and bio-accessibility.

\section{ACKNOWLEDGEMENTS}

We gratefully acknowledge the financial support for thisstudy from the National Natural Science Foundation of China (31271817), the Key Project of Science and Technology of Anhui (1501031099) and the Fundamental Research Funds for the Central Universities (J01001963).

\section{Authors' contributions}

Li-Yuan Zhou was the project leader and performed most of the experiments. Li Wan joined in the experiment design and implementation; Ya Wang, Wen-Qiang Guo were responsible for the completion of "In vitro gastrointestinal digestion"; Zheng-Nan Cai, Wei-Wei Yang, Dan-Dan Wang were responsible for the completion of "Analysis for free amino acids" and "Analysis for 5'-nucleotide".Sajid Hussain, Wen-Juan Pan, Yan Chen were responsible for modification and processing of the manuscript.

\section{REFERENCES}

Agosin, E., D. Diaz, R. Aravena and E. Yañez. 1989. Chemical and nutritional characterization of lupine tempeh. J. Food Sci. 54(1): 102-104.

Ahmed, F. A. and R. F. Ali. 2013. Bioactive compounds and antioxidant activity of fresh and processed white cauliflower. Biomed. Res. Int. 2013(1): 66-77.

AOAC. 2012. Official Methods of Analysis of AOAC International, $19^{\text {th }}$ ed. Association of Official Analytical Chemists, Gaithersburg, MD, USA.

Beluhan, S. and A. Ranogajec. 2011. Chemical composition and nonvolatile components of Croatian wild edible mushrooms. Food Chem. 124(3): 1076-1082.

Candela, M., A. I. Astiasaran and J. Bello. 1997. Cooking and warmholding: Effect on general composition and amino acids of kidney beans (Phaseolus vulgaris), chickpeas (Cicer arietinum), and lentils (Lens culinaris). J. Agric. Food Chem. 45(12): 4763-4767.

Chiang, P. D., C. T. Yen and J. L. Mau. 2006. Non-volatile taste components of canned mushrooms. Food Chem. 97(3): 431-437.

Choi, Y., S. M. Lee, J. Chun, H. B. Lee and J. Lee. 2006. Influence of heat treatment on the antioxidant activities and polyphenolic compounds of Shiitake (Lentinus edodes) mushroom. Food Chem. 99(2): 381-387.

Claudine, C., A. Jerome, M. Charpentier, P. Jeanclaude, A. B. Duteurtre and M. Feuillat. 2005. Release of nucleotides and nucleosides during yeast autolysis: Kinetics and potential impact on flavor. J. Agric. Food Chem. 53(8): 3000-3007.

Englyst, K. N. and H. N. Englyst. 2005. Carbohydrate bioavailability. Br. J. Nutr. 94(1): 1-11.

Jiang, T., Z. Luo and T. Ying. 2015. Fumigation with essential oils improves sensory quality and enhanced antioxidant ability of shiitake mushroom (Lentinus edodes). Food Chem. 172: 692-698.

Kalač, P. 2009. Chemical composition and nutritional value of European species of wild growing mushrooms: A review. Food 
Chem. 113(1): 9-16.

Kalač, P. 2013. A review of chemical composition and nutritional value of wild-growing and cultivated mushrooms. J. Sci. Food Agric. 93(2): 209-218.

Leksrisompong, P., P. Gerard, K. Lopetcharat and M. Drake. 2012. Bitter taste inhibiting agents for whey protein hydrolysate and whey protein hydrolysate beverages. J. Food Sci. 77(8): S282-S287.

Li, H., W. S. Nam, B. K. Moon and L. Chan. 2014. Antioxidant activity and phenolic content of brick caps mycelium (Naematoloma sublateritium) extracts. Food Sci. Biotechnol. 23(5): 1425-1431.

Li, Q., H. H. Zhang, I. P. Claver, K. X. Zhu, W. Peng and H. M. Zhou. 2011. Effect of different cooking methods on the flavour constituents of mushroom (Agaricus bisporus (Lange) Sing) soup. Int. J. Food Sci. Technol. 46(5): 1100-1108.

Liu, F., V. E. C. Ooi, W. K. Liu and S. T. Chang. 1996. Immunomodulation and antitumor activity of polysaccharide-protein complex from the culture filtrates of a local edible mushroom, Tricholoma lobayense. Gen. Pharmacol. Vasc. Syst. 27(4): 621-624.

Liu, Y., F. Huang, H. Yang, S. A. Ibrahim, Y. F. Wang and W. Huang. 2014. Effects of preservation methods on amino acids and 5'-nucleotides of Agaricus bisporus mushrooms. Food Chem. 149(149): 221-225.

Manzi, P., S. Marconi, A. Aguzzi and L. Pizzoferrato. 2004. Commercial mushrooms: Nutritional quality and effect of cooking. Food Chem. 84(2): 201-206.

Mau, J. L. 2005. The umami taste of edible and medicinal mushrooms. Int. J. Med. Mushrooms. 7(1): 119-126.

Mau, J. L., H. C. Lin and C. C. Chen. 2001. Non-volatile components of several medicinal mushrooms. Food Res. Int. 34(6): 521-526.

Melo-Ruiz, V., H. Sandoval-Trujillo, T. Quirino-Barreda, K. Sánchez-Herrera, R. Díaz-García and C. Calvo-Carrillo. 2015. Chemical composition and amino acids content of five species of edible grasshoppers from Mexico. Emirates J. Food Agric. 27(8): 654

Parada, J. and J. M. Aguilera. 2007. Food microstructure affects the bioavailability of several nutrients. J. Food Sci. 72(2): 21-32.

Pei, F., Y. Shi, X. Gao, F. Wu, A. M. Mariga, W. Yang, L. Zhao, X. An, Z. Xin and F. Yang. 2014. Changes in non-volatile taste components of button mushroom (Agaricus bisporus) during different stages of freeze drying and freeze drying combined with microwave vacuum drying. Food Chem. 165(3): 547-554.

Peleg, H., M. Naim, R. L. Rouseff and U. Zehavi. 1991. Distribution of bound and free phenolic acids in oranges (Citrus sinensis) and grapefruits (Citrus paradisi). J. Sci. Food Agric. 57(3): 417-426.

Phat, C., B. Moon and C. Lee. 2016. Evaluation of umami taste in mushroom extracts by chemical analysis, sensory evaluation, and an electronic tongue system. Food Chem. 192: 1068-1077.

Rodríguez-Roque, M. J., M. A. Rojasgraü, P. Elezmartínez and O. Martínbelloso. 2013. Soymilk phenolic compounds, isoflavones and antioxidant activity as affected by in vitro gastrointestinal digestion. Food Chem. 136(1): 206-212.

Stodolak, B. and S. S. Anna. 2008. The influence of tempeh fermentation and conventional cooking on anti-nutrient level and protein bioavailability (in vitro test) of grass-pea seeds. J. Sci. Food Agric. 88(13): 2265-2270.

Sun, L., Y. Zhuang and B. Xue. 2011. Effects of boiling and microwaving treatments on nutritional characteristics and antioxidant activities of Agaricus blazei Murril. Int. J. Food Sci. Technol. 46(6): 1209-1215.

Tsai, S. Y., S.J. Huang, L. Shenghua, T. P. Wu, P. Y. Lian and M. Jengleun. 2009. Flavour components and antioxidant properties of several cultivated mushrooms. Food Chem. 113(2): 578-584

Tian, Y., Yingting, H. Jijun, Z. Hongliang and Z. Baodong. 2016. Effects of different drying methods on the product quality and volatile compounds of whole shiitake mushrooms. Food Chem. 197: 714.

Van Boekel, M. A. 2006. Formation of flavour compounds in the Maillard reaction. Biotechnol. Adv. 24(2): 230-233.

Wang, C., Y. Chen, M. Hu, J. Ding, C. Xu and R. Wang. 2012. In vitro antioxidant activities of the polysaccharides from Tricholoma lobayense. Int. J. Biol. Macromol. 50(3): 534-539.

Wang, R., S. Ding, D. Zhao, Z. Wang, J. Wu and X. Hu. 2016. Effect of dehydration methods on antioxidant activities, phenolic contents, cyclic nucleotides, and volatiles of jujube fruits. Food Sci. Biotechnol. 25(1): 137-143.

Yamaguchi, S., T. Yoshikawa, S. Ikeda and T. Ninomiya. 1971 Measurement of the relative taste intensity of some L- $\alpha$-amino acids and 5'-nucleotides. J. Food Sci. 36(6): 846-849. 